\title{
Effect of Sowing Density on the Growth, Yield and Nutrient Uptake of Hybrid Sunflower (Helianthus annuus L.) in Rabi Season
}

\author{
S. Ravichandran* and N. Srinivasan \\ Department of Agronomy, Agriculture College and Research institute, \\ Tamil Nadu Agricultural University, Coimbatore \\ *Corresponding author
}

\begin{tabular}{|c|c|}
\hline & A B S T R A C T \\
\hline $\begin{array}{l}\text { Dry matter } \\
\text { production, Head } \\
\text { diameter, Number } \\
\text { of seeds per head, } \\
\text { Seed volume } \\
\text { weight. }\end{array}$ & \multirow{3}{*}{$\begin{array}{l}\text { The field experiments were conducted at Eastern Block farm of Tamil Nadu Agricultural } \\
\text { University during rabi season of } 2015 \text { and } 2016 \text {, to study the effect of different sowing } \\
\text { density and nutrient management on growth, yield and nutrient uptake of sunflower } \\
\text { (Helianthus annuus L.). The experiment was laid out in a randomized block design with } \\
\text { eleven treatment combinations and replicated thrice. The soil of the experimental field was } \\
\text { silty clay loam in texture, low in available nitrogen, medium in available phosphorus and } \\
\text { high in available potassium content. The sowing density of } 30 \mathrm{x} 30 \mathrm{~cm} \text { with single } \\
\text { seedling and } 200 \% \text { had accumulated the highest amount of DMP }(10987 \text { and } 12070 \mathrm{~kg} \text { ha- } \\
1 \text { during rabi season of } 2015 \text { and } 2016 \text { respectively) which was } 15 \% \text { higher than the lower } \\
\text { sowing density of } 60 \times 30 \mathrm{~cm} \text {. The yield parameters like head diameter (cm), number of } \\
\text { seeds per head, head weight, seed weight and seed volume weight were higher under the } \\
\text { sowing density of } 60 \times 30 \mathrm{~cm} \text { with single seedling and } 100 \% \text { RDF. The seed yield } \\
\text { significantly higher by adoption of } 30 \times 30 \mathrm{~cm} \text { with single seedling and application of } 200 \% \\
\text { RDF. }\end{array}$} \\
\hline Article Info & \\
\hline epted: & \\
\hline
\end{tabular}

\section{Introduction}

Sunflower (Helianthus annuus L.) is photo insensitive and not a season bound crop. It is the third most important oilseed crop after soybean and groundnut in the world. The area under sunflower in India is not sufficient to workout with the needs of growing population and to buildup the economy of the country.

Therefore, it should be our prior effort to find ways that can increase the yield by overcoming some constraints in the path of increasing productivity. Among various factors responsible for low yield in sunflower, management of fertilizers and planting population may be of much importance. In case of sunflower proper spacing provides sufficient interception of light and satisfactory absorption of nutrients and water from the soil due to the proper development of root system and results in higher crop yield. Seed yield was increased upto a plant population of 85000 plants $\mathrm{ha}^{-1}$ while beyond this had a depressing outcome on production. Higher plant density produce taller plants, lighter seeds and more yield than low plant population (Beg et al., 2007; Ishfaq et al., 2009). Nitrogen is a structural component of amino acids, protein and chlorophyll. Phosphorus is a constituent of ATP, ADP, Nucleic acids and Phospholipids. Potassium is 
involved in providing appropriate ionic environment for metabolic process, growth regulation, stomatal control, activation of enzymes and photosynthesis. But maximum inherent potential of a variety can only be achieved when nutrients are applied in balanced form with recommended dose of fertilizers (RDF) (Murali et al., 2009). Judicious application of N, P and K nutrient enhances the crop growth and development which helps in increasing seed yield and oil content.

Therefore, this study was conducted to find out the optimum sowing density and nutrient on its growth, yield and nutrient uptake.

\section{Materials and Methods}

A field experiments were conducted at Tamil Nadu Agricultural University, Coimbatore during rabi season of 2015 and 2016 to investigate the effect of planting density and nutrient management on growth, yield and quality of sunflower. The experimental site is geographically situated in the western agroclimatic zone of Tamil Nadu at $11^{\circ} \mathrm{N}$ latitude and $77^{\circ}$ E longitude and at an altitude of 426.7 meters above mean sea level (MSL). The study was conducted in randomized block design and replicated thrice. The treatment comprised of $60 \times 30$ with single seedling and $100 \%$ RDF $\left(\mathrm{T}_{1}\right), 60 \times 30 \mathrm{~cm}$ with two seedling per hill and $150 \% \operatorname{RDF}\left(\mathrm{T}_{2}\right)$, $60 \times 30 \mathrm{~cm}$ with two seedling per hill and $200 \%$ RDF $\left(\mathrm{T}_{3}\right), 60 \times 45 \mathrm{~cm}$ with two seedlings per hill and $125 \% \operatorname{RDF}\left(\mathrm{T}_{4}\right), 60 \times 45$ with two seedlings per hill and $150 \%$ RDF $\left(\mathrm{T}_{5}\right), 45 \times 45 \mathrm{~cm}$ with two seedling and $150 \%$ RDF $\left(\mathrm{T}_{6}\right), 45 \mathrm{x} 45 \mathrm{~cm}$ with two seedling with $200 \%$ RDF $\left(\mathrm{T}_{7}\right), 45 \times 30 \mathrm{~cm}$ with single seedling and $125 \%$ RDF $\left(\mathrm{T}_{8}\right), 45 \times 30 \mathrm{~cm}$ single seedling and $150 \% \mathrm{RDF}\left(\mathrm{T}_{9}\right), 30 \times 30$ $\mathrm{cm}$ with single seedling and $150 \% \mathrm{RDF}\left(\mathrm{T}_{10}\right)$, $30 \times 30 \mathrm{~cm}$ with single seedling and $200 \%$ $\operatorname{RDF}\left(T_{11}\right)$. The soil of the experimental field was sandy clay loam in texture belonging to Typic Ustropept. The nutrient status of the soil during start of the experiment was low in available nitrogen, medium in available phosphorus and high in available potassium. The field experiments were conducted during rabi season of 2015 and 2016. The sunflower hybrid, TNAU Sunflower Hybrid CO2 was used as test crop. The recommended fertilizer dose followed for sunflower was 90:60:60 kg NPK $\mathrm{ha}^{-1}$. Half dose of $\mathrm{N}$ and $\mathrm{K}$ and full dose of $\mathrm{P}$ were applied basally to all the treatments. The remaining $\mathrm{N}$ and $\mathrm{K}$ were top dressed at $30 \mathrm{DAS}$. The crop was harvested at maturity stage, seed yield per net plot of each treatment was recorded. Five plants were selected in each net plot area for measuring nutrients uptake. The various biometric observations, analytical data of plant sample and the computed data were subjected to statistical scrutiny as per the procedures given by (Gomez and Gomez, 1984). The treatment differences were worked out at five per cent probability level.

\section{Results and Discussion}

The results of the investigation with cause and effect of relationship and supported with relevant references based on experimental evidences were mentioned below.

\section{Effect on growth (Table 1)}

Data in table 1 revealed that, the sowing density and nutrient management exerted significant influence on growth characters of sunflower. Higher TDM (10987 and $12070 \mathrm{~kg}$ $\mathrm{ha}^{-1}$ during rabi season of 2015 and 2016 respectively) was accumulated by adopting $30 \times 30 \mathrm{~cm}$ with single seedling and $200 \%$ $\mathrm{RDF}$ as compared to $60 \times 30 \mathrm{~cm}$ with single seedling and $100 \%$ RDF (5602 and $6157 \mathrm{~kg}$ $\mathrm{ha}^{-1}$ in rabi season of 2015 and 2016 respectively). Sowing density and nutrient management had significant influence on number of leaves per hill was observed during 
rabi season of 2015 and 2016. The treatment $60 \times 30 \mathrm{~cm}$ with two seedlings per hill and application of $200 \%$ RDF significantly recorded 45.7 and 46.5 leaves per hill during Rabi2015andRabi2016 respectively at 90 DAS. This may be due to the two plants accommodated in a hill in the treatment resulted in higher number of leaves.

On 90 DAS, $T_{1}(60 \times 30 \mathrm{~cm}$ with single seedling and $100 \%$ RDF) significantly recorded higher stem girth of $7.15 \mathrm{~cm}$ and $7.19 \mathrm{~cm}$ during Rabi 2015 and 2016 respectively. This was due to less competition between the plants which leads to the better utilization of available resources viz., light, moisture and nutrients at optimum plant population. The lower stem girth was recorded at closer spacing due to the high competition between the plants for nutrient, moisture and light. These results are in concurrence with those of Vijayakumar and Ramesh (2005). The root volume (75.1 and $75.0 \mathrm{cc}$ during rabi 2015 and 2016 respectively) and root dry weight (58.7 and 59.3 gin rabi 2015 and 2016 respectively) was higher under the $60 \times 30 \mathrm{~cm}$ with single seedling and $100 \%$ RDF.

\section{Growth analysis (Table 2)}

The plant population favourably influenced the LAI and the high plant population $\left(\mathrm{T}_{3}\right)$ registered the higher LAI at all the stages. LAI of 17.46 and 14.87 during rabi 2015 and 2016 was recorded under $\mathrm{T}_{3}$. Significant influence on CGR and RGR was observed during the course of investigation. The highest CGR and RGR value was recorded in $\mathrm{T}_{11}$. This may be due to the higher number of leaves per hill and higher leaf area per hill which reflected on the higher value of LAI. Moreover, wider space availability between the rows and optimum intra row spacing might have increased the root spread which eventually utilized the applied nutrients and water effectively, which reflected on higher leaf area and more number of leaves per hill. This might be attributed to the minimal competition among the plants under this treatment, which might have provided sufficient space to the crop to harness the solar energy and utilization of applied nutrients and moisture effectively, which reflected on leaf area and dry matter production per plant. Moreover, the lesser value of spacing $\left(900 \mathrm{~cm}^{2}\right)$ in numerator might have increased the CGR and RGR of the treatment (Kumar et al., 2011).

Yield parameters and seed yield (Tables 3 and 4)

During rabi season of 2015 and 2016, the $\mathrm{T}_{1}$ $(60 \times 30 \mathrm{~cm}$ with single seedling and application of $100 \% \mathrm{RDF}$ ) recorded higher head diameter $(34.5 \mathrm{~cm}$ and $32.2 \mathrm{~cm}$ respectively) as against the lower head diameter recorded in $45 \times 45 \mathrm{~cm}$ with two seedling per hill and application of $150 \%$ RDF $\left(\mathrm{T}_{6}\right)$. The same trend followed in other characters viz., seeds per head, 100 seed weight and seed volume weight. This may be due to the sufficient of environmental conditions in wide spacing and less competition between plants as well as increase light penetration within plant canopy which increased assimilation rate and oil formation. These results are in a good line with those obtained by Yakout et al., (1992), Sharief (1998), Allam et al., (2003), Ruffo et al., (2003), Ali and Osman (2004), And Tenebe et al., (2008). The sowing density and different nutrient levels had exerted a significant positive influence on seed yield of sunflower. Sunflower grown at $30 \times 30 \mathrm{~cm}$ with single seedling and $200 \%$ RDF produced higher seed yield (2992 and $3232 \mathrm{~kg} \mathrm{ha}^{-1}$ ) over $60 \times 30 \mathrm{~cm}$ with single seedling and $100 \%$ RDF. These results are in a good line with those obtained by Sloan et al., (2003) and ElMohandes et al., (2005) on sunflower. 
Table.1 Effect of planting density and nutrient management on number of leaves per hill and dry matter production $\left(\mathrm{kg}^{\mathrm{a}} \mathrm{a}^{-1}\right)$ at 90 DAS of sunflower during rabi season

\begin{tabular}{|c|c|c|c|c|c|}
\hline & & \multicolumn{2}{|c|}{ No. of leaves per hill } & \multicolumn{2}{|c|}{ DMP $\left(\mathrm{kg} \mathrm{ha}^{-1}\right)$} \\
\hline \multicolumn{2}{|r|}{ Treatment } & 2015 & 2016 & 2015 & 2016 \\
\hline $\mathbf{T 2}$ & $60 \times 30$ Two seedling with $150 \%$ RDF & 42.8 & 41.6 & 8312 & 9365 \\
\hline T4 & $60 \times 45$ Two seedling with $125 \%$ RDF & 37.0 & 37.1 & 6512 & 7412 \\
\hline T5 & $60 \times 45$ Two seedling with $150 \%$ RDF & 39.9 & 38.2 & 6608 & 7679 \\
\hline T6 & $45 \times 45$ Two seedling with $150 \%$ RDF & 34.1 & 32.2 & 7185 & 8856 \\
\hline T9 & $45 \times 30$ Single seedling with $150 \%$ RDF & 27.9 & 27.6 & 6713 & 8537 \\
\hline T10 & $30 \times 30$ Single Seedling with $150 \%$ RDF & 24.0 & 22.5 & 10049 & 11166 \\
\hline \multirow[t]{3}{*}{ T11 } & $30 \times 30$ Single Seedling with $200 \%$ RDF & 25.3 & 26.2 & 10987 & 12070 \\
\hline & SEd & 1.3 & 1.4 & 411 & 426 \\
\hline & CD (0.05) & 2.8 & 2.9 & 859 & 890 \\
\hline
\end{tabular}

Table.2 Effect of planting density and nutrient management on stem girth (cm), root volume (cc) and root dry weight (g) of sunflower at 90 DAS during rabi season

\begin{tabular}{|c|c|c|c|c|c|c|c|}
\hline & & \multicolumn{2}{|c|}{ Stem girth $(\mathrm{cm})$} & \multicolumn{2}{|c|}{ Root volume (cc) } & \multicolumn{2}{|c|}{ Root dry mass (g) } \\
\hline \multicolumn{2}{|r|}{ Treatment } & 2015 & 2016 & 2015 & 2016 & 2015 & 2016 \\
\hline T1 & $60 \times 30$ Single seedling with $100 \%$ RDF & 7.15 & 7.19 & 75.1 & 75.0 & 58.3 & 65.8 \\
\hline $\mathbf{T} 2$ & $60 \times 30$ Two seedling with $150 \%$ RDF & 4.85 & 4.85 & 43.5 & 43.5 & 27.0 & 29.4 \\
\hline T3 & $60 \times 30$ Two seedling with $200 \%$ RDF & 5.01 & 5.01 & 45.2 & 45.2 & 27.7 & 30.1 \\
\hline T4 & $60 \times 45$ Two seedling with $125 \%$ RDF & 5.08 & 5.08 & 46.9 & 46.8 & 29.5 & 32.0 \\
\hline T5 & $60 \times 45$ Two seedling with $150 \%$ RDF & 5.12 & 5.12 & 49.6 & 49.6 & 29.6 & 32.1 \\
\hline T6 & $45 \times 45$ Two seedling with $150 \%$ RDF & 4.51 & 4.51 & 33.7 & 33.7 & 21.8 & 23.7 \\
\hline T7 & $45 \times 45$ Two seedling with $200 \%$ RDF & 4.61 & 4.61 & 35.9 & 35.9 & 24.9 & 27.1 \\
\hline T8 & $45 \times 30$ Single seedling with $125 \%$ RDF & 6.07 & 6.09 & 63.5 & 63.5 & 49.5 & 56.5 \\
\hline T9 & $45 \times 30$ Single seedling with $150 \%$ RDF & 6.61 & 6.64 & 69.2 & 69.1 & 54.2 & 61.3 \\
\hline T10 & $30 \times 30$ Single Seedling with $150 \%$ RDF & 5.15 & 5.15 & 53.0 & 53.0 & 41.2 & 45.4 \\
\hline \multirow[t]{3}{*}{ T11 } & $30 \times 30$ Single Seedling with $200 \%$ RDF & 5.57 & 5.57 & 58.1 & 58.1 & 44.9 & 51.1 \\
\hline & SEd & 0.25 & 0.25 & 2.4 & 2.4 & 1.8 & 1.9 \\
\hline & CD (0.05) & 0.52 & 0.53 & 5.1 & 5.1 & 3.7 & 4.1 \\
\hline
\end{tabular}


Table.3 Effect of planting density and nutrient management on growth analytical parameters of sunflower during rabi season

\begin{tabular}{|c|c|c|c|c|c|c|c|}
\hline \multirow{2}{*}{\multicolumn{2}{|c|}{ Treatment }} & \multicolumn{2}{|c|}{ LAI } & \multicolumn{2}{|c|}{$\begin{array}{c}\text { CGR } \\
\left(\mathrm{g} \mathrm{m}^{-2} \text { day }^{-1}\right)\end{array}$} & \multicolumn{2}{|c|}{$\begin{array}{c}\text { RGR } \\
\left(\mathrm{mg} \mathrm{g}^{-1} \text { day }^{-1}\right)\end{array}$} \\
\hline & & 2015 & 2016 & 2015 & 2016 & 2015 & 2016 \\
\hline T1 & $60 \times 30$ Single seedling with $100 \%$ RDF & 6.80 & 6.92 & 2.15 & 2.24 & 2.03 & 2.12 \\
\hline $\mathbf{T 2}$ & $60 \times 30$ Two seedling with $150 \%$ RDF & 15.27 & 12.82 & 2.56 & 2.62 & 3.84 & 4.05 \\
\hline T3 & $60 \times 30$ Two seedling with $200 \%$ RDF & 17.46 & 14.87 & 2.85 & 2.95 & 4.21 & 4.54 \\
\hline $\mathbf{T 4}$ & $60 \times 45$ Two seedling with $125 \%$ RDF & 8.00 & 7.00 & 1.59 & 1.60 & 2.05 & 2.18 \\
\hline T5 & $60 \times 45$ Two seedling with $150 \%$ RDF & 9.10 & 7.26 & 1.69 & 1.80 & 2.09 & 2.19 \\
\hline T6 & $45 \times 45$ Two seedling with $150 \%$ RDF & 8.67 & 7.39 & 2.00 & 1.98 & 2.15 & 2.24 \\
\hline T7 & $45 \times 45$ Two seedling with $200 \%$ RDF & 10.00 & 8.18 & 2.16 & 2.27 & 2.27 & 2.29 \\
\hline T8 & $45 \times 30$ Single seedling with $125 \%$ RDF & 7.24 & 7.80 & 2.24 & 2.57 & 2.53 & 2.79 \\
\hline T9 & $45 \times 30$ Single seedling with $150 \%$ RDF & 7.53 & 8.94 & 2.28 & 2.85 & 3.35 & 2.93 \\
\hline T10 & $30 \times 30$ Single Seedling with $150 \%$ RDF & 10.51 & 9.13 & 3.21 & 3.31 & 4.75 & 5.25 \\
\hline \multirow[t]{3}{*}{ T11 } & $30 \times 30$ Single Seedling with $200 \%$ RDF & 12.19 & 10.69 & 3.49 & 3.65 & 5.21 & 5.73 \\
\hline & SEd & 0.47 & 0.46 & 0.11 & 0.12 & 0.16 & 0.17 \\
\hline & CD (0.05) & 0.99 & 0.97 & 0.24 & 0.25 & 0.33 & 0.37 \\
\hline
\end{tabular}

Table.4 Effect of planting density and nutrient management on yield parameters of sunflower during rabi season

\begin{tabular}{|c|c|c|c|c|c|c|c|c|c|}
\hline \multirow{2}{*}{\multicolumn{2}{|c|}{ Treatment }} & \multicolumn{2}{|c|}{$\begin{array}{l}\text { Head diameter } \\
(\mathrm{cm})\end{array}$} & \multicolumn{2}{|c|}{ No. of seeds head ${ }^{-1}$} & \multicolumn{2}{|c|}{$\begin{array}{l}\text { Head weight } \\
\text { (g) }\end{array}$} & \multicolumn{2}{|c|}{$\begin{array}{c}\text { Seed volume weight } \\
(\mathrm{g})\end{array}$} \\
\hline & & 2015 & 2016 & 2015 & 2016 & 2015 & 2016 & 2015 & 2016 \\
\hline T1 & $60 \times 30$ Single seedling with $100 \%$ RDF & 34.5 & 32.2 & 1485 & 1499 & 24.7 & 24.6 & 38.3 & 42.1 \\
\hline $\mathbf{T} 2$ & $60 \times 30$ Two seedling with $150 \%$ RDF & 21.4 & 21.3 & 986 & 963 & 15.5 & 16.0 & 28.4 & 39.1 \\
\hline T3 & $60 \times 30$ Two seedling with $200 \%$ RDF & 22.4 & 21.8 & 996 & 975 & 16.0 & 16.2 & 28.5 & 36.1 \\
\hline T4 & $60 \times 45$ Two seedling with $125 \%$ RDF & 23.7 & 22.0 & 1010 & 983 & 16.2 & 16.3 & 28.5 & 32.7 \\
\hline T5 & $60 \times 45$ Two seedling with $150 \%$ RDF & 24.3 & 22.5 & 1028 & 995 & 16.7 & 16.5 & 28.8 & 29.7 \\
\hline T6 & $45 \times 45$ Two seedling with $150 \%$ RDF & 18.6 & 19.5 & 957 & 945 & 14.0 & 15.2 & 28.0 & 29.2 \\
\hline T7 & $45 \times 45$ Two seedling with $200 \%$ RDF & 21.0 & 20.1 & 974 & 957 & 15.2 & 15.4 & 28.1 & 28.7 \\
\hline T8 & $45 \times 30$ Single seedling with $125 \%$ RDF & 28.6 & 26.0 & 1249 & 1205 & 21.4 & 20.5 & 32.3 & 28.5 \\
\hline T9 & $45 \times 30$ Single seedling with $150 \%$ RDF & 31.2 & 28.7 & 1365 & 1308 & 23.1 & 22.7 & 35.2 & 28.5 \\
\hline T10 & $30 \times 30$ Single Seedling with $150 \%$ RDF & 26.1 & 23.1 & 1081 & 999 & 18.0 & 18.1 & 29.1 & 24.7 \\
\hline \multirow[t]{3}{*}{ T11 } & $30 \times 30$ Single Seedling with $200 \%$ RDF & 27.6 & 25.2 & 1143 & 1101 & 19.7 & 18.6 & 29.3 & 24.2 \\
\hline & SEd & 1.2 & 1.1 & 48 & 49 & 0.8 & 0.8 & 1.4 & 1.3 \\
\hline & CD (0.05) & 2.4 & 2.3 & 101 & 102 & 1.6 & 1.6 & 2.8 & 2.8 \\
\hline
\end{tabular}


Table.5 Effect of planting density and nutrient management on seed yield $\left(\mathrm{kg} \mathrm{ha}^{-1}\right)$ and nutrient uptake $\left(\mathrm{kg} \mathrm{ha}^{-1}\right)$ of sunflower during rabi season

\begin{tabular}{|c|c|c|c|c|c|c|c|c|c|}
\hline \multirow{2}{*}{\multicolumn{2}{|c|}{ Treatment }} & \multicolumn{2}{|c|}{$\begin{array}{c}\text { Seed yield } \\
\left(\mathrm{Kg} \mathrm{ha}^{-1}\right)\end{array}$} & \multicolumn{2}{|c|}{$\begin{array}{l}\text { N Uptake } \\
\left(\mathrm{Kg} \mathrm{ha}^{-1}\right)\end{array}$} & \multicolumn{2}{|c|}{$\begin{array}{l}\text { P Uptake } \\
\left(\mathrm{Kg} \mathrm{ha}^{-1}\right)\end{array}$} & \multicolumn{2}{|c|}{$\begin{array}{l}\text { K Uptake } \\
\left(\mathrm{Kg} \mathrm{ha}^{-1}\right)\end{array}$} \\
\hline & & 2015 & 2016 & 2015 & 2016 & 2015 & 2016 & 2015 & 2016 \\
\hline T1 & $60 \times 30$ Single seedling with $100 \%$ RDF & 2021 & 2041 & 34.5 & 38.2 & 11.0 & 12.3 & 76.9 & 86.2 \\
\hline $\mathbf{T} 2$ & $60 \times 30$ Two seedling with $150 \%$ RDF & 2381 & 2404 & 50.1 & 53.7 & 18.7 & 18.2 & 130.6 & 130.6 \\
\hline $\mathbf{T 3}$ & $60 \times 30$ Two seedling with $200 \%$ RDF & 2604 & 2655 & 56.1 & 59.1 & 20.0 & 20.0 & 141.3 & 143.1 \\
\hline $\mathbf{T 5}$ & $60 \times 45$ Two seedling with $150 \%$ RDF & 2240 & 2262 & 39.6 & 44.5 & 13.3 & 15.4 & 93.0 & 107.5 \\
\hline T6 & 45 x 45 Two seedling with $150 \%$ RDF & 2327 & 2349 & 40.0 & 44.7 & 14.5 & 16.2 & 101.6 & 111.7 \\
\hline $\mathbf{T 7}$ & 45 x 45 Two seedling with $200 \%$ RDF & 2348 & 2371 & 40.3 & 47.3 & 15.1 & 17.1 & 105.7 & 119.5 \\
\hline T8 & $45 \times 30$ Single seedling with $125 \%$ RDF & 2350 & 2373 & 44.5 & 51.5 & 13.2 & 17.2 & 92.5 & 124.0 \\
\hline & SEd & 115 & 118 & 2.2 & 2.5 & 0.8 & 0.9 & 5.8 & 5.9 \\
\hline & CD (0.05) & 245 & 247 & 4.7 & 5.3 & 1.7 & 1.8 & 12.1 & 12.5 \\
\hline
\end{tabular}




\section{Nutrient uptake (Table 5)}

Among the different treatments, significantly higher uptake of nitrogen, phosphorus and potassium (66.7 and 71.5 $\mathrm{kgha}^{-1}, 21.3$ and $24.5 \mathrm{kgha}^{-1}, \quad 145.3$ and $169.2 \mathrm{kgha}^{-}$ ${ }^{1}$ respectively during rabi 2015 and 2016) was noticed with $30 \times 30 \mathrm{~cm}$ with single seedling and $200 \% \mathrm{RDF}$ as compared to $60 \times 30 \mathrm{~cm}$ with single seedling and 100\% RDF (34.5 and $38.2 \mathrm{kgha}^{-1}, 11$ and $12.3 \mathrm{kgha}^{-1}, 76.9$ and 86.2 $\mathrm{kgha}^{-1}$ respectively during rabi 2015 and 2016). Higher nutrient uptake in higher plant population level is attributed to more below and aboveground competition for nutrients and all the applied resources are effectively utilized, which in turn resulted in higher seed yield. This result is in conformity with the findings of Devand Sarawgi (2004).

It is concluded that, sowing density of $30 \mathrm{~cm}$ apart row to row and $30 \mathrm{~cm}$ plant to plant distances with single seedling and application of $200 \%$ RDF proved to give higher productivity in sunflower hybrid $\mathrm{SFH} \mathrm{CO}_{2}$. Therefore $\mathrm{SFH} \mathrm{CO}_{2}$ should be planted with a $30 \times 30 \mathrm{~cm}$ with single seedling and 200\% $\mathrm{RDF}$ in order to exploit its maximum yield potential.

\section{References}

Ali, E.A. and. Osman, E.B.A. 2004. Effect of hill spacing fertigation using drip irrigation system in sandy calcareous soil on the productivity of some safflower genotypes. The 2nd Syrian Egyptian Conf.

Allam, A.Y., El-Nagar, G. R and Galal, A.H. 2003. Response of two sunflower hybrids to planting dates and densities. ActaAgronomica Hungarica, 51(1): 2535

Beg, A., Pourdad, S.S and Alipour, S. 2007. Row and plant spacing effects on agronomic performance of sunflower in warm and semi-cold area of Iran. Hella, 30(47): 99-104.

Dev, C.M. and Sarawgi, S.K. 2004. Balance sheet of nitrogen,phosphorus and potassium as influenced by spacing and nutrient management in sunflower, Helianthus annuus L. J. Oilseeds Res., 21(1): 187-188

El-Mohandes, Salwa, Ali, E.A. and Osman, E. B.A. 2005. Response of two sunflower hybrids to the number of NPK fertilizers splittings and plant densities in newly reclaimed soil. Assiut J. Agric. Sci., Vol 36(5): 27-38.

Gomez, K.A. and Gomez, A.A. 1984. Statistical procedures for agricultural research, 2nd edn., John Wiley and Sons. New York. p.680.

Ishfaq, M., Ali, A., Khaliq, A., and Yaseen, M. 2009. Allometry, agronomic traits and yield of autumn planted sunflower hybrids under varying row spacing. Pak. J. Agric. Sci., 46: 248- 257.

Kumar, S., Tewari, S.K. and Singh, S.S. 2011. Effect of sources and levels of sulphur and spacing on the growth, yield and quality of spring sunflower (Helianthus annuus). Indian J. Agron., 56(3): 242246.

Murali, A.P., Balasubramanian, T.N. and Amanullah, M.M. 2009. Impact of climate and nutrient management on yield components and yield of sunflower (Helianthus annuus L.). Am.Eurasian J. Sustain. Agric., 3: 13-16

Ruffo, M.L., Garcia, F.O., Bollero, G.A., Fabrizzi, K., and Ruiz, R.A. 2003. Nitrogen balance approach to sunflower fertilization. Communications in Soil Sci. and Plt. Analysis., 34(17- 18): 2645-2657

Sharief, A.E. 1998. Productivity of some introduced sunflower cultivars as affected by planting date and plant population density. Zagazig J. Agric. Res., 25(6): 895 - 909. 
Sloan, R.C., Harkness, S.S. and Reel, K.L. 2003. Effect of spacing on sunflower production. Annual Report of the North Mississippi Research and Extension Center, Mississippi Agriculture and Forestry Experiment Station Information Bull., 398: 475-478.

Tenebe, V.A., Pal, U.R., Okonkwo, C.A.C. and Auwalu, B.M. 2008. Response of rainfed sunflower (Helianthus annuus L.) to nitrogen rates and plant population in the semi-arid savanna region of Nigeria. J. Agron. and Crop Sci., 177(3): 207-2015.
Vijayakumar, M. and Ramesh, S. 2005. Effect of crop geometry and nitrogen management on growth analysisand yield of rain-fed sunflower (Helianthus annuиs). J. Ecotoxicol. Environ. Monitoring, 15(4): 371-376.

Yakout, G.M., Awad, A., Abdel-Wahab, A.M. and. Griesh, M.H.M. 1992. Effect of some agronomic practices on sunflower production. 2-planting date and planting distances on yield and its components of some sunflower cultivars. Ann. Agric. Sci. Moshtohor, 30: 109-126.

\section{How to cite this article:}

Ravichandran, S. and Srinivasan, N. 2017. Effect of Sowing Density on the Growth, Yield and Nutrient Uptake of Hybrid Sunflower (Helianthus annuus L.) in Rabi Season. Int.J.Curr.Microbiol.App.Sci. 6(7): 4193-4200. doi: https://doi.org/10.20546/ijcmas.2017.607.434 